\title{
God will reward you: Muslim practices of caring for precarious migrants in the context of secular suspicion
}

\author{
Christine M. Jacobsen ${ }^{1}$
}

Accepted: 25 June 2021 / Published online: 31 July 2021

(c) The Author(s) 2021

\begin{abstract}
In recent years, Muslims have become more visibly invested in humanitarian work in France. Based on ethnographic fieldwork in Marseille, this article examines local initiatives to care for precarious others whose lives are neither materially supported nor socially recognized within the current French political regime. Engaging with critical French scholarship on humanitarianism as care for others associated with emergency, suffering and the politics of compassion, I show how food-distribution (maraudes) by Muslim-run humanitarian associations also draw from Islamic ethics of care. While social dynamics related to gender, class, race and generation structure the maraudes, the foregrounding of shared precarity, and of religious duty and piety over pity, challenges the 'hierarchies of deservingness' established by humanitarian border regimes. In caring for precarious others, Muslims must navigate both the secular suspicion directed towards Islam and the securitization of migration. Carrying out the religious duty of helping those in need, they are 'laying claim to public space' for both Muslims and precarious migrants.
\end{abstract}

Keywords Irregular migration · Secular suspicion · Humanitarianism · Islam · France

\section{Introduction}

'Bonsoir. One or two? Do you want a spoon?' I am at the end of the table, providing sugar cubes for the coffee poured in plastic cups by Hamid, a tall man in his early thirties. A small group of volunteers, mainly of North African descent, struggle to serve the around 150-200 men, women and children who have queued up, in separate lines, for the daily food distribution. Yusef is streaming the event to the organization's Facebook page, describing the food

Christine M. Jacobsen

christine.jacobsen@uib.no

1 Department of Social Anthropology, University of Bergen, P box 7802, 5020 Bergen, Norway 
distributed by volunteers and thanking the donors': 'Tonight, we had vegetable soup with crème fraiche, couscous, pizza, pastries, fruit, cakes, and coffee. Many thanks to all who donated food and to the volunteers who made this maraude possible. May God reward you generously'.

In recent years, French Muslims have become more visibly invested in humanitarian and charity work, focusing not only on countries in the global South torn by war and poverty, but increasingly also on the local context. In Marseille, the secondlargest city in France with its close to 900000 inhabitants, and home to one of its largest and most diverse Muslim populations, one of the first such investments was by a mosque women's group in the quartiers nord, one of the poorest suburbs in France. During my fieldwork in 2012, 'the sisters' cooked a meal every Friday after the salat al-jumu'ah, which 'the brothers' drove off to distribute to homeless people in the evening. ${ }^{2}$ From their modest office in the mosque, the women's group also distributed clothes and household necessities to those in need. When I came back to do fieldwork on the situation of irregularized migrants in Marseille in 2017, I discovered that many of them depended on the meals by then distributed on a daily basis by volunteer organizations.

Doing participant observation for my project on waiting and the temporalities of irregular migration (Jacobsen et al., 2020), I attended food distribution organized by different organizations on several occasions, sometimes participating as a volunteer, sometimes going there with my migrant interlocutors, or sometimes just observing the activities from a distance. In addition to participant observation, I base my analysis in this article on interviews and informal conversations with both organizers, volunteers (bénévoles) and recipients, as well as on the self-presentation of the organizations on their websites and Facebook pages, and in local media.

The food distributions are referred to as maraudes, which is an ancient term for 'circling' or 'turning around' in the dark (often to steal fruit). Maraudes were put to new use from the 1990s, notably with the social policies established under former president Jaques Chirac (in office 1995-2007), to describe outreach-work providing care for people in need. While the food maraudes in Marseille started as mobile teams, many became 'fixed' when the target population grew too large for one circling car to reach all in the course of one night. On the nights I participated during fieldwork, we would usually cater to somewhere between 100 and 300 people. Initially, the maraudes mainly provided for homeless people (les sans-abri). With the intensification of migrant arrivals related to the so-called Arab Spring and the war in Syria, as well as numerous armed conflicts and socio-economic hardship across Africa, and in conjunction with cutbacks in welfare provision to migrants, the sans-abri came to include increasing numbers of homeless and precarious migrants - among them many who lack a legal status, in French called the sans-papiers.

\footnotetext{
1 In addition to individual donations, food donations are also made by grocery stores, bakeries and restaurants.

2 Such kinship terminology is commonly used among Muslim volunteers, indexing their common faith and values, and creating a morally appropriate framework for interaction between women and men.
} 
Anthropological studies of contemporary French humanitarianism emphasise its hybrid religious and secular genealogy (Ticktin, 2011a; Fassin, 2007). More specifically, contemporary humanitarianism, Ticktin (2011a: 64) argues, 'brings together the ideals of the Right of Man with an inheritance from the Catholic Church'. ${ }^{3}$ While Ticktin traces the genealogies of care of French humanitarianism through Catholic charity, I seek to introduce a religious tradition of care that has until now mainly been absent from discussions of humanitarianism in France, namely traditions of Islamic charity. This article accordingly seeks to broaden, and complicate, the understanding of contemporary French humanitarianism 'at home', through an ethnographic inquiry into the multi-layered motivations and ethics that entangle humanitarian impulses, and Muslim religiosity in the mauraudes of Marseille. Like Juul Petersen (2015:4) I am interested in how these organizations present and understand themselves, their religion and the aid they provide, exploring how they respond to and are shaped by the context out of which they have grown.

In contemporary France, religious practices are constantly scrutinized for ulterior motives, and the borders between the religious and the secular, the private and the public are patrolled, but also transgressed. Islam in particular is the object of 'secular suspicion' - a scrutiny of religious practices and symbols for potentially harbouring what is seen as ulterior, corrupting motives - and efforts to regulate religious practice in public space (Agrama, 2012b; Fernando, 2014; Jacobsen, 2017). Frequently when I spoke to friends and colleagues about distributing food with Muslim-run organizations, they would inquire, 'Is their humanitarian work a cover up for proselytising activities or are they really there to help?'. Proselytizing has indeed been repeatedly problematized in French debates over laïcité (the particular French version of secularism), especially the attribution of a proselytizing effect to the Islamic headscarf (see e.g. Jacobsen, 2017). Such scrutiny might be seen as a kind of secular vigilance against religious power and its potential abuse, but it is also a consequence of the 'securitization' of Islam and migration in recent years.

The secular problematization of Islam articulates with emotions and values, norms and obligations, mobilized by authorities around migration, which in the 2000s could be described in terms of security - internationally through the so-called war on terror - and in France related to inner city youth and urban violence, as well as a national fight against Islamist terror understood to threaten French values and norms (Fassin, 2009). In Marseille, the securitization of Islam and irregular migration reached a peak in October 2017, after a man killed two women at the St. Charles train station with a knife, while, according to witnesses, pronouncing Allahu Akbar (God is Great). Newspapers reported the perpetrator to be an irregular migrant, suffering severe mental health issues, which further energized the links drawn in public debate between Islam and irregular migration as security challenges.

With this context in mind, this article discusses how people organizing and participating in food distribution present and understand the aims of the organizations

\footnotetext{
3 There exist of course diverse Catholic engagements with humanitarianism. See for instance WalkerSaid (2015) for a discussion of rival Catholic visions for humanitarian practice and its entanglements with colonialism.
} 
and the motivations of volunteers. What are the "moral economies" ${ }^{4}$ that animate and sustain food distribution and other care organized by Muslim maraudeurs? How are Islamic traditions of care negotiated in the context of 'secular suspicion' characterising contemporary France (Agrama, 2012a, b; Jacobsen, 2017)?

\section{Food distribution as care for precarious lives}

There was a number of smaller voluntary organizations involved in food distribution. Some organizations attracted mainly practising Muslims, and many were of North African background, but the volunteers at maraudes were a mixed group in terms of religious, political, ethnic, gender, age and class positions. Some were themselves children of migrants having grown up in poor areas in the city, others were foreign students temporarily residing in Marseille, and yet others again white majority French. Volunteers could include members of established organizations, friends and relatives of the organizers, as well as people who discovered the work of the maraudes online or in passing by as food distribution took place.

Organizers and volunteers often referred to the particularity of the local context as central to their engagement. Crucial to this was the image of Marseille as a city of immigration and mixity, but also as a city of shared precarity and solidarity. The founder of one of the maraudes explained that, 'In Marseille there is a lot of solidarity, because the Marsaillais are themselves dans la precarité.'Precarity relates back to the Latin precaria, from precārius, 'obtained by prayer, given as a favour,' and precari, 'to ask, beg, pray', and is recurrent in French public debate about socioeconomic hardship and inequality. In particular, it invokes the idea of insecurity, revocability and instability in having one's basic needs met, which is the case for many inhabitants of certain Marseille neighbourhoods that are among the poorest areas of contemporary France.

In her contribution to the growing academic literature on precarity, Butler (2004, 2009) distinguishes between precariousness and precarity. Whereas precariousness refers to vulnerability to the other as part of bodily life, precarity refers to how such corporeal vulnerability is distributed globally in radically inequitable ways so that lives are supported and maintained differently (2004:30-32). Precarity thus relates to how social value is ascribed to some lives and bodies, while it is denied to others, and to how some are protected, while others are not. It 'designates that politically induced condition in which certain populations suffer from failing social and economic networks of support and become differentially exposed to injury, violence, and death' (Butler, 2009:25). In modern France, caring for the bodily life and welfare of inhabitants has been systematized as the domain of the secular welfare

\footnotetext{
4 I am indebted to Fassin's (2009:37) discussion of 'moral economy' as 'the production, distribution, circulation and use of moral sentiments, emotions and values, and norms and obligations in social space'. As Fassin (2009:47) stresses '[...] moral economies are unstable or at least fluid realities traversed by tensions and contradictions, since conflicts of emotions and values oppose as much as they divide social groups, but also subject to change and negotiations, according to circumstances and configurations.'.
} 
state. The reconfiguration of the welfare state in recent times, has however, 'led to a renewed need for help or support to treat the marginalized and excluded, categories that are incorporating more and more of the population' (Ticktin, 2011a, :68).

The French state's neo-liberal privatisation and withdrawal of its welfare services from certain categories of people from the 1970s onwards (Bourdieu, 1993:220) has articulated with an increasingly stricter border regime, and the irregularization of migrants (Fassin, 2012b). Access to public welfare for migrants has been restricted, and enrolled in a politics of deterrence and discouragement, the idea being that welfare benefits attract more migrants. Irregularized migrants in particular, are excluded from so-called universal welfare arrangements, and left to be cared for through exceptional humanitarian measures distributed by the state on a case-by-case basis (such as the 'illness clause'), ${ }^{5}$ or by humanitarian and charity organizations. Irregularized migrants are at heightened risk of disease, poverty, starvation and of exposure to violence with little or no protection. As such, they have come to embody the 'suffering stranger within', challenging the North/South imaginary of humanitarianism that locates suffering 'over there' (cf. Malkki, 2015).

The politics of food assistance is one example of how lives are differently supported and maintained. Irregularized migrants are not alone in depending on food assistance, but their living conditions reinforce nutritional precarity, including lack of financial resources to buy sufficient and nourishing food, and housing conditions where cooking facilities are scarce or lack altogether. For a large part, food assistance is not organized by the state or local authorities, but by a multitude of humanitarian and charity organizations. ${ }^{6}$ Access to food assistance is heterogeneous, and while meals are mostly distributed without any justification required, the distribution of food packages may in some cases require some form of administrative justification (cf. César, 2008). To have access to the 'social restaurant' in Marseille, for instance, one has to be referred by one of the collaborating associations, and for access to food packages in some organizations one has to justify a lack of resources e.g. attesting that your only income is the allocation for asylum seekers (ADA), and in others one has to pay a small participation (cf. Observatoire Asile Marseille, 2018).

Food distribution is not just about sustaining biological life, although survival is of course a crucial concern to those whose lives are not supported and maintained by the French welfare state. To many migrants, the lack of food, and lack of choices as to what to eat, perpetuated a feeling of abandonment and lack of influence over their own life. This was the case for Joseph who told me one evening as we were queuing up to eat at the maraude that 'You do not eat food that you choose yourself. When you are given food, there are things that you cannot eat, but that you are

\footnotetext{
5 See Ticktin $(2006,2011 \mathrm{a})$ and Musso $(2012,2017)$ on how the suffering body came to represent the pure victim cared for in the French humanitarian regime, as institutionalised in the provision allowing foreigners who suffer from illnesses that cannot be treated in their home country to be temporarily regularised in France.

${ }^{6}$ Including notably La Croix-Rouge, le Secours Populaire, la Banque Alimentaire et les Restos du Cœur which are part of the FEAD (Fund for European Aid to the Most Deprived), which distributes surplus food in the European union.
} 
forced to eat. That's the life of a man who does not have a choice'. Many noticed changes to their bodies due to long-term reduced calorie intake or an unhealthy diet. While people from some geographic regions and classes are not unfamiliar with being abandoned by the state or relying on charity, the sense of abandonment was sometimes conveyed to me as a question of having expected European welfare regimes, and France in particular, to honour human and social rights. ${ }^{7}$

\section{Caring for humanity}

While some organizations foregrounded local identity, and solidarity as a response to precarity, other organizations stressed the 'humanitarian' character of their work. Abid, a convert to Islam, son of immigrants and co-founder of one organization, explained to me that: "We wanted to englobe everyone. We did not want any religious connotations, so that no one would be penalised and believe that it is an association that only helps Muslims. [...] We are trying to be a humanitarian organization; I think that in the humanitarian, there are no religious distinctions". The inscription of food distribution in a humanitarian discourse reflects the legal regulation of voluntary associations under the Law of 1901 - a law that was a consequence of efforts to separate state and church and diminish the power and influence of the Catholic Church and clergy. ${ }^{8}$ The 1905 law on the separation of Church and State also allowed religious communities to organize as private associations (association cultuelle), but these were to be uniquely devoted to exercise of the cult, and excluded cultural, social and humanitarian activities. ${ }^{9}$ Interestingly, the law thus excludes charity from 'the cult', despite its centrality as a religious practice in many religious traditions, including Christianity and Islam. The French humanitarian and charitable sectors, ranging from the secularist Secours Populaire to the Catholic NGO Secours Catholique, thus became sites of contest over where to draw the line between the religious and the secular, the public and the private, the political and the ethical.

Naming their organization 'humanitarian' was also related to the association of 'humanitarianism' with the universal recognizability of human suffering and nondifferentiation of recipients. Abid was aware of the widespread understanding of universalism in the context of French republicanism and laïcité, in which religious approaches are perceived to be particularistic, discriminatory and excluding (cf. Fernando, 2014:51). To avoid such perceptions of the organization, the claim

\footnotetext{
7 The International Covenant on Economic, Social and Cultural Rights protects the right for people to feed themselves in dignity, implying that sufficient food is available, that people have the means to access it, and that it adequately meets the individual's dietary needs. This obligation does not oblige states to distribute free food to everyone, but to ensure (among other things through welfare arrangements), the possibility to access food.

8 Voluntary organizations in France have been on the rise throughout the twentieth century, especially after the Second World War, and count more than a million associations related to sports, cultural activities, vindication of rights and support of causes, or for health and social services.

9 Since 1981 also foreign residents have the right to form associations.
} 
to 'englobe everyone' was made in the name of a humanitarian universalism in which 'there are no religious distinctions'.

Humanitarian aid organizations also promote the humanitarian ideal of nondiscrimination of recipients, which many contemporary Islamic charities equally stress (Bellion-Jourdan, 2000). This ideal also guided the practical organization of food distribution at maraudes through the queue, which is commonly seen as a non-discriminatory distributive principle (Young, 2016). The main principle was the first come first served, and everyone had the 'right' to one hot dish, one piece of bread, and a choice of yoghurt, fruit or cake. The non-discrimination of recipients was repeatedly stressed by the maraudeurs, also in their account of what moved them to action. One of the organization's founding moments was the freezing-to-death of a homeless former police officer sleeping outside the train station in Marseille. Recognizing the man's death as a life to be grieved is what prompted them to 'do something' to support lives exposed to injury, violence, and death, Abid told me.

Juul Petersen (2015) contrasts the universalist notion of humanity underpinning secular humanitarianism with Islamic aid culture, which is centred on notions of solidarity and brotherhood, binding Muslims together in a global umma. Putting the question of whether volunteers are 'doing it for humanity or for the umma?' at the centre of her investigation into differing ideologies of aid in transnational Muslim NGOs, she argues that in the latter perspective, all Muslims are part of the same religious brotherhood, and as such, closely connected, mutually interdependent and obliged to help one another. The idea of the umma - a global community of Muslims - has a complex genealogy in the Islamic discursive tradition which cannot be given any justice here (but see e.g. Asad, 2003; Devji, 2010). The same goes for the concept of humanity - as an indivisible collective of human beings, which as Fassin (2007:518) argues is both recent and fragile. As feminist scholars have argued, secular ideas of humanity may also involve ideas of 'brotherhood'. Hyndman (1998) for instance, notes a tendency in the history of UNHCR humanitarianism to conceptualize humanity in terms of a 'universal brotherhood'. French republicanism similarly has 'brotherhood' as one of its three pillars, with the gendered and racialized exclusions this has historically implied.

In the context of the maraudes, concepts such as 'people in need', the precarious', and 'the destitute', were frequently used, whereas references to ideological framings relating to 'humanity' and 'the umma' were rare. When I brought the question of 'for whom' they carried out voluntary work up for Yama, the co-organizer of one of the maraudes, he located human unity in a religious cosmology 'We are all one community, one people, we all descend from Adam, at least to the believers, and we are all human'. A volunteer in one of the other organizations similarly stressed that 'Those in need are not Muslim or non-Muslim, they are in need. And in need, that includes everyone'. Rather than a sharp distinction between humanity and the umma as collectives of solidarity and care, entangled secular and religious conceptualizations co-existed in the maraudes. Accordingly, food distribution may be seen as local sites of encounter between various aid cultures, and religious and secularist traditions of care for others. 


\section{Care as Islamic duty and the hope of religious reward}

The humanitarian work carried out by the maraudeurs was for many intimately entangled with Islamic ethics and religious piety. Ahmed, a pious bearded young man of immigrant background explained to me,

'To me, it is a religious duty. I have the possibility to do good, so why should I deprive myself. But then you also hope for reward. The one who helps someone in need will be helped the day he is himself in need. At the religious level, the reward is enormous. If you feed someone in need, you will be rewarded. To us, Islam is not just praying five times a day, it is also all the other things, like helping those in need. It is very very good to give food to those in need (miskin).'

The Arabic term miskin means 'poor, miserable', and is used in the Qur'an about those whom it is a duty for believers to support. ${ }^{10}$ It locates care in a tradition of aid provision grounded on Muslim practices and an ethos of caring for the poor (Atia, 2013; Sparre, 2018). Many of those who participated at the food distribution pointed out that caring for those in need was a religious duty. Islamic tradition prescribes $z a k a t$, obligatory alms calculated according to income and wealth, ${ }^{11}$ and sadaqa, voluntary donations such as money, food, or time, that can be given by anyone in any context. In thanking contributors, organizers would typically say 'may Allah accept your sadaqa' or 'we thank all our donors for their sadaqa'. Caring for those in need was seen as crucial to being a pious Muslim, and also brought forth the question of religious reward. Reward can be both about God's help when needed in this life and promises of a reward in the afterlife. Many Muslims believe that good acts (hasanat) are rewarded with divine recompense (ajar and thawab), spoken of as 'points', 'merit', and 'scores' (cf. Jacobsen, 2011; Juul Petersen, 2015; Mittermaier, 2014). The idea of reward was central to mobilising people to make donations and participate in the maraudes. Appeals would be posted by organizers on Facebook, telling followers (in the social media sense) to: 'Come and join us at least once, God will give you back. Misery can strike anyone at any moment.' Organizers would thank the donors by asking Allah to reward them generously. People who 'liked' and supported the maraudes in social media often asked God to recompense organizers and volunteers generously for their work.

Interestingly, only to a small extent did the maraudes mobilise through eliciting emotions of compassion as a response to suffering. The Facebook pages were virtually void of the images and narratives of suffering that are associated with global humanitarianism, and that NGOs use to raise funding (Fassin, 2012a). Rather,

\footnotetext{
${ }_{10}$ Buhl, in First Encyclopaedia of Islam, 1913-1936, Volume 5, p. 220. The term has passed from Arabic into French as mesquin/mesquina, used more generally to express pity ('the poor thing').

${ }^{11}$ Islamic scholars differ in their opinion whether funds collected as zakat can be disbursed for the benefit of non-Muslims as well as Muslims, but several important Islamic humanitarian organizations have adopted the former view (Benthall, 2016). In France zakat is organized either privately or through individual donations to mosque and religious associations, and is therefore largely a question of one's individual conscience and piety.
} 
photos and videos were almost uniquely of the food served and the volunteers serving it. Beyond contributing to preserving the anonymity of the recipients, this also illustrates how volunteering at the maraudes points to a different form of relationality between donor and recipient, which is not merely or even mainly figured as compassion or pity for suffering victims. While in the cases of Islamic care culture that Juul Petersen (2015) discusses, the invisibility of the (individual) recipient is matched by the visibility of individual donors, the maraudes tended not to name, thank or portray individual donors, but to focus instead on the food that had been donated and the joint effort that volunteers made to care for those in need.

In her study of the Egyptian charity organization, Resala, Mittermaier (2014) argues that good works done as a duty to God radically diverge from a secular humanist ethics of being good and caring for others as a human virtue in itself. In contrast to the 'altruist imperative' of secular humanitarian ethics, which makes all forms of personal gain and satisfaction (even a 'good conscience') problematic, and privileges empathy, care, and compassion (Muehlebach, 2012, 2013), the idea of good work as a duty to God highlights interdependence and a relationship of obedience toward God. The practice of dutiful giving, Mittermaier (2014) argues, can help provincialize the concept of compassion-a concept with strong Christian, liberal, and humanist connotations but one that is often taken to drive voluntarism globally. As she rhetorically puts it (2014:525); 'Whereas Fassin points out that "we love to feel pity" (2012a:251), Resala volunteers do not love to feel pity; they love to accrue points.' A similar argument can be made with regard to the maraudeurs in Marseille. The focus on religious duty and reward problematizes the affective structure of compassion, and links volunteering to an ethics of religious piety and pious self-making. Including the volunteer work done by Muslims into the analysis, thus helps broaden, and complicate, the critical anthropological appreciation of contemporary French humanitarianism 'at home' and opens towards other moral economies than those traced by Ticktin (2011a) and Fassin (2009, 2012a).

\section{Humanitarian selves and others}

In the critical literature on contemporary humanitarianism (Ticktin 2011a, Fassin, 2007, 2009, 2012a, Malkki, 2015) a recurring topic is the way in which humanitarian discourses tend to establish a hierarchical (and often spatialized) distinction between helpers and those in need of help, or what Fassin (2007:507) identifies as two constructions of life: the life that is saved, that of the victims, and the life that is risked, that of those intervening. In contrast, volunteers at the maraudes in Marseille insisted on the similarity between themselves and the people they were distributing food to. The idea that 'misery can strike anyone at any moment' foregrounded shared precariousness rather than a sharp distinction between helpers/helped, haves/have nots. Sometimes volunteers drew on personal experiences of migration, loss and hardship, reducing the distance to those they cared for, and bringing in an economic and political dimension of precarity in Butler's (2004) sense. One evening Edouard approached the maraudeurs for a blanket to help him keep warm at night. Visibly tense, Edouard told us about his struggle to get by as an irregularized migrant: $\mathrm{He}$ 
had worked informally on a construction site, but had not received payment, and had nowhere to stay. 'There is nothing left for me in Marseille', he declared, and explained that he had visited the boat terminal to assess the possibility of travelling clandestinely to Canada or the US. Faced with our warnings about the dangers of travelling illegally by sea, Edouard replied that the alternative was no better; staying on for a slow death. In response, Zidan pulled out his phone and played a YouTube clip of a sermon about the virtue of being strong when afflicted by accidents. 'You have to be strong', Zidan repeated, and went on to tell the story of how his own family had lost all their investments in their home country, a former French African colony, and how they had come to Marseille and fought to establish a new life. 'You must do the same', Zidan encouraged Edouard, 'You must not give up, but fight until the very end'. 'I know, I know', Edouard mumbled, 'I am just so tired'.

While the distinction between the carer and the cared for in this situation was mainly a temporal one (between newcomers and those migrants who had managed to establish themselves), the social choreography of food distribution also contributed to a spatialized distinction. The tables set up for serving food simultaneously served as a material border between the carers and the cared for. While the diverse make up of both categories made it hard to tell from appearance alone whether someone was there to distribute or receive food, being positioned behind or in front of the table determined your status. The material and symbolic boundary became clear to me during participant observation. Moving between participating and observing from a position in the queue and a position behind the table in the course of one night was difficult and seemed to create confusion on the part of maraudeurs as well as beneficiaries. I thus chose to participate and observe from different positions on different nights.

One evening, Nassim's teenage daughter ventured out to the other side of the table, in an effort to organise the distribution more effectively. Immediately, one of the male veterans, functioning as a guard and in charge of keeping order in the lines, admonished her: 'Get behind the table, these men are not good', appealing at the same time humorously to her father; 'Look, he has his gloves on (referring to the rubber glows used by volunteers during the food distribution for hygienic purposes as if they were boxing gloves to be used in protecting his daughter). As for instance Ticktin (2011b) and Malkki (2015) have noted, humanitarian work and voluntarism tend to be highly gendered. In the case of the maraudes, women's participation in food distribution required their physical presence at night in a time-space largely coded as unsafe for women. The characterization of the men as 'not good' resonates with widespread perceptions of racialized migrant men as dangerous, but in this case may equally be related to a gendered coding of time-space and concerns with female virtue and purity. Despite such concerns, both the preparation of food and its distribution was mixed gender at the maraudes where I participated, with 'sisters' and 'brother's working side by side to care for others in need.

The ideal of care for others driven by a compassion devoid of self-interest is said to characterises secular humanitarian intention (Malkki, 2015). Critical research on humanitarianism has argued that a unilateral focus on compassion with the other tends to produce hierarchies of deservingness (Ticktin 2011a, b, Fassin, 2009, 2012a). In general, however, motivations related to religious duty and reward seem 
to depend less on distinguishing the 'deserving' from the 'undeserving', and more on the question of the giver's intention (niyyat) to enact God's will, which is crucial to the idea of pious practice and religious reward. The maraudes did no evaluation of people's needs and required no documentation or registration. Despite this, limits as to who needed and deserved to be cared for were occasionally marked by volunteers who complained about people who took 'more than their share' or who dismissed certain populations as 'not really in need'. Nassim, a regular at the maraudes, made a point of how some North-African migrants had come to earn money, had family in Marseille, and did not really need food assistance but were trying to save up as much money to send back (often to build a house in their home village) as possible. This suspicion resonates with broader social discourses about 'deservingness', and the distinction between 'economic' and 'forced' migration in France and beyond (Holmes \& Castaneda, 2016; Ticktin, 2011a).

Sometimes, questions of deservingness were linked more directly to racializing stereotypes. While Annais, who volunteered at maraudes every week saw food distribution as a form of sadaqa that brought her closer to God, such giving could have its costs, she ventured. Recently her car had been robbed and trashed by some Roma people she had just given food. Annais also told me that Roma people were known to try to pass as Muslims during the month of Ramadan, in order to gain more sympathy and donations from Muslims. Comparative anthropological literature shows that such conceptions of Roma people as 'bogus' refugees and as posing as other groups to gain legitimacy and receive resources exist also elsewhere in Europe (Holmes \& Castaneda, 2016). On another occasion, some volunteers bringing private donations to an asylum holding centre outside the city were disappointed to meet a group of drunk disinterested young men. The pious intention to care in this case turned to indignation over the moral shortcomings of the migrants, who did not fit their imaginary of suffering Muslim brothers in need. These examples point to moral (and other) limits as to who is to be considered 'in need' and who is deserving of being cared for. Mittermaier (2014:527) is right that the Islamic focus on duty, reward and intention allows the imagining of 'modes of giving that, unlike compassion, do not re-inscribe binary and asymmetrical power relations between humanitarian subjects and objects of compassion - precisely because they are not about the Other but about something that exceeds human interest and feelings of compassion'. However, differences related to gender, race, ethnicity and religion still parse questions of moral deservingness and conjugate volunteer practices of care.

During the distribution of food at maraudes, interaction with those who came to eat was mostly limited to greetings (in French, Arabic or occasionally English) and certain pious invocations. When the food service was over though, occasions sometimes arose for more interaction between volunteers and beneficiaries. Abid told me that their activities were not limited to distributing food, they also tried to offer other forms of help, including lending an ear to those who needed someone to talk to. Such moments could also be occasions for 'reminding them of God'. One evening as we were packing up, Abid introduced me to a man who had been coming to the maraudes to eat for several years. Struggling to get papers in France, he had started drinking. Thanks to Abid and 'the brothers', the man told me, he was now drinking much less, 'walking straight', and had a job and a small apartment. Abid explained 
to me, 'If you only tell them drinking is bad for their health, they may not listen to you. But if you remind them about God and what Islam says about alcohol, then maybe you can scare them to stop'. Reminding people of God here serves a double purpose of carrying out the religious duty to actively encourage fellow Muslims in the pursuance of greater piety, and of more effectively caring for others, by appealing not only to the necessity of caring for oneself, but also of obeying religious prescriptions and proscriptions.

The maraudes were also framed as occasions for inter-generational transmission of moral sentiments, emotions, and values to young people, including such virtues as gratefulness, humility, and the duty to help others. The capacity to care for others was contextualized in relation to the particular struggles of each migrant generation. While the 'first generation' had struggled to settle in Marseille, youth who grow up in the suburbs today (of the so-called second or third generation) felt excluded from French society. As Hamid explained to me, 'Unemployment is rampant, often they are tempted to take the short cut to earning money [i.e. selling drugs]. Why should they take a job for 1000 euros a month where they have to get up at 08.00 when they can make 4000 euros with flexible hours? Participating in the maraudes will help them understand how privileged they are even if they are discriminated against in French society, and make them avoid the short cut.' Similarly, one of the volunteers named Aisha, who often brought her children, told me that 'children should not get everything in their hands. They should learn how cruel the world is and how some people who are less fortunate than them live'. ${ }^{12}$ Here, we see that while a common situation of precarity is said to underpin local solidarity, distinctions are nevertheless established between the fortunate/unfortunate, the privileged/unprivileged and between different forms of precarity and exclusion from French society.

\section{Care and/as compassion, control, and (de)politicization}

In his analysis of various humanitarian projects in France and elsewhere, Fassin (2012a) has developed a compelling case for a deep change in social imaginaries, one in which an ethics of suffering and compassion has come to displace a politics of rights and justice for those facing inequality, violence or hardship. According to Fassin (2012a: 4) humanitarian ideals, which direct our attention to the suffering of others and make us want to remedy it, underpin the discourse and legitimise the practices of government agencies, local administrations as well as charities that seek to manage, regulate and support the existence of 'precarious lives'. Humanitarian reason has become a generalised mode of government, where administrators look for evidence of physical and mental suffering in deciding whether to grant immigrants asylum, or to provide financial assistance to the unemployed, the poor, the sans-abris and the sans-papiers. The shift identified by Fassin and others is arguably

\footnotetext{
12 As André Iteanu, an anthropologist with many years of experience in social work in France, pointed out to me, this discourse resembles the one of social workers doing youth work in disadvantaged French suburbs.
} 
somewhat overstated, in the sense that a politics of rights and justice never entirely replaced religious discourses of charity in the first place (cf. Davis \& Taithe, 2011), nor is contemporary secular humanitarian work necessarily void of Catholic sentiment and motivation (Fassin, 2007; Siméant, 2009). In its various versions, however, contemporary humanitarianism, with its focus of suffering and compassion, arguably creates new 'hierarchies of deservingness', and 'casualties of care', as not all suffering counts equally (Butler, 2009; Fassin, 2012a; Ticktin, 2011a, b).

While inscribed in a humanitarian discourse, the mauraudes differed from the 'humanitarian reason' described by Fassin (2012a) and Ticktin (2005, 2011a) on important accounts. Firstly, the question of suffering and compassion, and of deservingness, was not the only or even a dominant framework, as it entangled with ideas of shared precariousness and religious piety. Secondly, rather than establishing a clear distinction between those who offer care and those who are cared for, volunteers cultivated an awareness that those positions may be reversed in time so that the one caring for others now, is one previously cared for or potentially 'in need' in the future. Thirdly, unlike the 'humanitarian reason' described by Fassin and Ticktin, the temporal framework of the mauraudes was not exceptionalism and emergency. Rather - caring for those in a precarious situation was seen as a permanent religious obligation.

Critics of contemporary humanitarianism have suggested that it depoliticizes the question of suffering and serves as a form of antipolitics. According to Ticktin (2011a), the highly emotional language of humanitarianism distracts from questions of rights. Malkki (2015) has similarly argued that classical humanitarianism is mandated to be apolitical, 'Such humanitarian approaches to, for instance refugees as ahistorical subjects of - merely "human", merely "victims" -depoliticizes and hinders our understanding of their actual circumstances, yielding the perverse result of the humanitarianism that dehumanizes (and sometimes actively harms) its objects by reducing actors in a complex and meaningful historical process into nakedly human objects of compassion, zö̈, or in Agamben's terms "bare life".' (Malkki, 2015:199). From such a critical perspective, the maraudes could be seen as a part of a humanitarian anti-politics machine, and in worst case as perpetuating dependency rather than pushing for political solutions. And yet, as Malkki also notes in her study of Finnish humanitarian aid workers, there is more to it than that (2015:199).

Volunteering at the maraudes is characterised by multi-layered motivations and ethics that entangle humanitarian impulses and religious piety such as caring for humanity, promoting human dignity, living piously, and religious merit. While some humanitarian NGOs also advocate for migrants' rights, the maraudes run by Muslims usually do not participate in activist political mobilisation. However, with the increased criminalisation of help to migrants (what has been termed 'solidarity offenses'), ${ }^{13}$ and the increased securitization of public space, the line between

\footnotetext{
13 The so-called 'crime of solidarity' (délit de solidarité) refers to article L-622-1 of the Code de l'entrée et du séjour des étrangers et du droit d'asile (CESEDA), which criminalises direct or indirect facilitation of the irregular entry, circulation or stay of migrants. Reacting to two controversial sentences in 2017, the French Constitutional Council, later upheld, in the name of the principle of fraternity, the freedom to provide humanitarian assistance without taking into consideration the person's legal status Cons. Const. (France), décision n $2018-717 / 718$ Q.P.C. du 6 juillet 2018.
} 
ethics and politics is far from clear cut. The religious ethics of duty and reward that is mobilised at the maraudes is about acting and responding regardless of migrants' motives, circumstances, and outcomes. As such, it resists current attempts to govern migration through assessment of legitimacy, and to criminalize care for those who the state defines as undeserving. The maraudeurs assured me that even if they were to be denied the permission to distribute food as a consequence of the increased securitization of Islam and migration and the criminalization of solidarity, it would not stop them from carrying out the religious duty of helping those in need. In so doing, they are 'laying claim to public space' (Butler, 2009), and the presence of both religious practice (in the form of caring for those in need) and irregularized migrants in the public space of the French republic.

Importantly, irregularized migrants are not only cared for. They also care for themselves and take care of others. Future research will have to address the many forms of care and solidarity that irregularized migrants develop among themselves, for instance pooling resources to buy food, cooking for others when you have worked or got some food, or receiving a newcomer among those who are more settled and have an income of some sort. Many also care for family and kin in the places they left, by sending back remittances, even when their situation is characterised by extreme precarity. Migrants whose lives are not sustained through public welfare arrangements, struggle to sustain their lives and that of others through various practices of care. As such, they contribute to challenging the depoliticizing humanitarian dichotomisation of subjects and objects of compassion and care.

Funding Open access funding provided by University of Bergen (incl Haukeland University Hospital).

Open Access This article is licensed under a Creative Commons Attribution 4.0 International License, which permits use, sharing, adaptation, distribution and reproduction in any medium or format, as long as you give appropriate credit to the original author(s) and the source, provide a link to the Creative Commons licence, and indicate if changes were made. The images or other third party material in this article are included in the article's Creative Commons licence, unless indicated otherwise in a credit line to the material. If material is not included in the article's Creative Commons licence and your intended use is not permitted by statutory regulation or exceeds the permitted use, you will need to obtain permission directly from the copyright holder. To view a copy of this licence, visit http://creativecommons.org/licen ses/by/4.0/.

\section{References}

Agrama, H. (2012). Questioning secularism: Islam, sovereignty and the rule of law in Egypt. University of Chicago Press.

Agrama, H. (2012b). The politics of religious freedom: Religious freedom as a binding practice of suspicion. The immanent Frame. Retrieved from Religious freedom as a binding practice of suspicion - The Immanent Frame (ssrc.org) (Accessed 02.06.2021).

Asad, T. (2003). Formations of the secular. Christianity, Islam and modernity. Stanford: Stanford University Press

Atia, M. (2013). Building a house in heaven: Pious Neoliberalism and Islamic charity in Egypt. University of Minnesota Press.

Bellion-Jourdan, J. (2000). Islamic relief organizations: Between 'Islamism' and 'Humanitarianism.' ISIM Newsletter, 5(00), 15. 
Benthall, J. (2016). Islamic charities and Islamic humanism in troubled times. Manchester University Press.

Buhl, Fr. (1913-1936). 'Miskīn'. In M. T. Houtsma, T. W. Arnold, R. Basset, R. Hartmann (Eds.), Encyclopaedia of Islam, First Edition. Consulted online on 26 July 2021 https://doi.org/10.1163/2214871X_ei1_SIM 4695

Bourdieu, P. (1993). La demission de l'État. In P. Bourdieu (Ed.), La misère du monde (pp. 219-228). Seuil.

Butler, J. (2004). Precarious life: The powers of mourning and violence. Verso.

Butler, J. (2009). Frames of war: When is life grievable? Verso.

César, C. (2008). Dépendre de la distribution d'aide alimentaire caritative : Le cas de sans-papiers, Anthropology of food, [Online] 6 (September 2008). https://doi.org/10.4000/aof.5073.

Davis, A. J., \& Taithe, B. (2011). From the purse and the heart: Exploring charity, humanitarianism, and human rights in France. French Historical Studies, 34(3), 413-432. https://doi.org/10.1215/00161 071-1259184.

Devji, F. (2010). The language of Muslim Universality. Diogenes, 226, 35-49. https://doi.org/10.1177/ 0392192110393205

Fassin, D. (2012a). Humanitarian reason: A moral history of the present. University of California Press.

Fassin, D. (2012b). Les nouvelles frontières de la société française. La Découverte.

Fassin, D. (2009). Moral economies revisited. Annales. Histoire, Sciences Sociales, 64(6), 1237-1266.

Fassin, D. (2007). Humanitarianism as a politics of life. Public Culture, 19(3), 499-520. https://doi.org/ 10.1215/08992363-2007-007.

Fernando, M. (2014). The Republic Unsettled: Muslim French and the Contradictions of Secularism. Duke University Press.

Holmes, S. \& Castaneda, H. (2016). Representing the "European Refugee Crisis" in Germany and beyond. Deservingness and difference. Life and death. American Ethnologist, 43(1), 12-24. https:// doi.org/10.1111/amet.12259.

Hyndman, J. (1998). Managing difference: Gender and culture in humanitarian emergencies. Gender, Place and Culture, 5(3), 241-260. https://doi.org/10.1080/09663699825197

Jacobsen, C. M., Karlsen, M.-A., \& Khosravi, S. (2020). Waiting and the temporalities of irregular migration. Routledge. https://doi.org/10.4324/9780429351730

Jacobsen, C. M. (2017). Veiled nannies and secular futures in France. Ethnos, 83(3), 5445-5566. https:// doi.org/10.1080/00141844.2017.1313288.

Jacobsen, C. M. (2011). Islamic traditions and Muslim Youth in Norway. Brill.

Juul Petersen, M. (2015). For humanity or for the Umma? Aid and Islam in transnational Muslim NGOs. Hurst \& Co.

Malkki, L. H. (2015). The need to help. The domestic Arts of International humanitarianism. Duke University Press.

Mittermaier, A. (2014). Beyond compassion: Islamic voluntarism in Egypt. American Ethnologist, 41(3), 518-531. https://doi.org/10.1111/amet.12092

Muehlebach, A. (2013). On precariousness and the ethical imagination: The year 2012 in sociocultural anthropology. American Anthropologist, 115(2), 297-311. https://doi.org/10.1111/aman.12011.

Muehlebach, A. (2012). The moral neoliberal: Welfare and citizenship in Italy. University of Chicago Press.

Musso, S. (2017). Comment l'anthropologie de la santé éclaire certains enjeux des migrations. Idées Économiques Et Sociales, 189(3), 20-27. https://doi.org/10.3917/idee.189.0020

Musso, S. (2012). Être régularisé au titre de la maladie en France. Corps, Corps des affects - Corps en migrations. CNRS Éditions, 10, 153-163. https://doi.org/10.3917/corp1.010.0153

Observatoire Asile Marseille. (2018). L'asile en exil. État des lieux de l'accueil des personnes en demande d'asile à Marseille 2017-2018.

Siméant, J. (2009). Socialisation catholique et biens de salut dans quatre ONG humanitaires françaises. Le Mouvement Social, 2(2), 101-122. https://doi.org/10.3917/lms.227.0101

Sparre, S. L. (2018). Experimenting with alternative futures in Cairo: Young Muslim volunteers between god and the nation. Identities, 25(2), 158-175. https://doi.org/10.1080/1070289X.2017.1400276

Ticktin, M. (2011a). The gendered human of humanitarianism: Medicalising and politicising sexual violence. Gender \& History, 23(2), 250-265. https://doi.org/10.1111/j.1468-0424.2011.01637

Ticktin, M. (2011b). Casualties of care: Immigration and the politics of humanitarianism in France. University of California Press. 
Ticktin, M. (2006). Medical humanitarianism in and beyond France: Breaking down or patrolling borders? In A. Bashford (Ed.) Medicine at the Border: The History, Culture and Politics of Global Health (pp.116-135). Bastingstoke: Palgrave. https://doi.org/10.1057/9780230288904_7.

Ticktin, M. (2005). Policing and Humanitarianism in France: Immigration and the turn to law as state of exception. Interventions: International Journal of Postcolonial Studies 7(3), 3475-368. https://doi. org/10.1080/13698010500268148.

Young, K. G. (2016). Rights and queues: On distributive contests in the modern state. Columbia Journal of Transnational Law 55(431), 65-37. Available at SSRN: https://ssrn.com/abstract=2892648.

Walker-Said, C. (2015). Science and charity: Rival catholic visions for humanitarian practice at the end of empire. French Politics, Culture \& Society, 33(2), 33-54. Available at https://www.jstor.org/stable/26378230.

Publisher's note Springer Nature remains neutral with regard to jurisdictional claims in published maps and institutional affiliations. 